\title{
Are biochemical tests of thyroid function of any value in monitoring patients receiving thyroxine replacement?
}

\author{
W D FRASER, E M BIGGART, D ST J O'REILLY, H W GRAY, J H MCKILLOP, \\ J A THOMSON
}

\begin{abstract}
To establish their role in monitoring patients receiving thyroxine replacement biochemical tests of thyroid function were performed in 148 hypothyroid patients studied prospectively. Measurements of serum concentrations of total thyroxine, analogue free thyroxine, total triiodothyronine, analogue free triiodothyronine, and thyroid stimulating hormone, made with a sensitive immunoradiometric assay, did not, except in patients with gross abnormalities, distinguish euthyroid patients from those who were receiving inadequate or excessive replacement.

These measurements are therefore of little, if any, value in monitoring patients receiving thyroxine replacement. To stop doing thyroid function tests in these cases would result in considerable savings nationally in the cost of reagents in laboratories using commercial kits.
\end{abstract}

\section{Introduction}

The development and application of free thyroid hormone assays ${ }^{1}$ and sensitive thyroid stimulating hormone assays ${ }^{2}$ during the past five years has led to the reappraisal of the best biochemical tests of thyroid function in different disease states. There is considerable controversy over which tests should be used to monitor patients receiving thyroxine replacement for primary hypothyroidism, in whom the detection of over-replacement poses a problem. Different authors have claimed that over-replacement is best detected by measuring the serum concentration of total thyroxine, ${ }^{3}$ total triiodothyronine, ${ }^{4}$ free thyroxine, ${ }^{5}$ or free triiodothyronine.$^{6}$ The value of some of these tests has been questioned, ${ }^{78}$ while others have recommended measuring both thyroid stimulating hormone, using a sensitive method, and free triiodothyronine..$^{90}$ Euthyroid patients receiving thyroxine replacement have higher serum thyroxine and free thyroxine concentrations than normal euthyroid subjects. This is not so for serum triiodothyronine and free triiodothyronine concentrations. ${ }^{61112}$

This study was undertaken to establish a reference range for

Department of Biochemistry, Royal Infirmary, Glasgow G4 OSF

W D FRASER, $M B$, registrar

E M BIGGART, BSC, research scientist

D ST J O'REILLY, MRCPATH, consultant

Department of Medicine, Royal Infirmary, Glasgow

II W GRAY, FRCP, consultant physician

J H MCKILIOP, MRCP, serior lccturer

J A THOMSON, FRCP, reade?

Correspondence to: Dr Fraser. thyroid function tests in patients receiving thyroxine replacement and to try to select the best test or combination of tests to monitor treatment.

\section{Patients and methods}

A prospective study was carried out in 148 hypothyroid patients (with primary hypothyroidism or after radioiodine treatment or thyroidectomy) attending a thyroid outpatient clinic. There were 131 female and 17 male patients aged, respectively, 14-89 (mean (SD) 52.9 (15.1)) years and $18-75(52 \cdot 6(13.6)$ years. They had been taking thyroxine replacement for more than three months, and none was taking drugs known to interfere with thyroid hormone metabolism, protein binding, or the assays used. The prescribed daily dose of thyroxine varied from 50 to $300 \mu \mathrm{g}$ (mean 124.6 (49.5)). The patients were classified as clinically euthyroid, hyperthyroid, or hypothyroid by the examining physician after a full history and clinical examination and with use of a modified Wayne clinical diagnostic index. ${ }^{13}$ The clinical assessments were carried out by three consultants and a registrar, who were experienced in thyroid disease. Subsequently blood samples were taken between 0900 and 1130 and the serum stored at $-20^{\circ} \mathrm{C}$ before assay.

Total thyroxine and triiodothyronine concentrations were measured by in house radioimmunoassay and thyroid stimulating hormone by an in house immunoradiometric assay using antisera obtained from the Scottish Antibody Production Unit, Carluke ML8 5ES. The detection limit for the assay of thyroid stimulating hormone is $0.1 \mathrm{mU} / 1 .{ }^{14}$ Analogue free thyroxine and free triiodothyronine were measured using Amerlex kits (Amersham International).

\section{Results}

On clinical examination, supported by the Wayne index, 108 patients were judged to be euthyroid, 22 to be hyperthyroid, and 18 to be hypothyroid. Table I shows the results of biochemical tests in these three groups.

To test whether individual clinicians showed bias in diagnosing hypothyroidism or hyperthyroidism the distribution of the Wayne index scores assigned to patients by each of the four clinicians was examined by KruskalWallis analysis of variance. There was no significant difference in the four median scores (figure)

The mean dose of thyroxine received by patients who were hyperthyroid was higher (137 (42) $\mu \mathrm{g})$ but not significantly different from the dose received by patients who were euthyroid (128 (50) $\mu \mathrm{g}$ ). Hypothyroid patients received a significantly lower dose $(88(38) \mu \mathrm{g})$ than euthyroid patients $(p<0 \cdot 01)$. There was no significant difference in the mean age of the patients in each clinical group.

Table II shows the conventional reference ranges and new reference ranges for euthyroid patients receiving thyroxine $(95 \%$ confidence intervals of the cumulative frequency distribution). Table III shows the number of patients in each clinical group who were misclassified by the conventional and new reference ranges. Thyroid stimulating hormone was undetectab!e by the sensitive assay-that is, below $0.1 \mathrm{mU} / 1$ - in 34 of the euthyroid patients, nine of the hyperthyroid patients, and three of the hypothyroid 
patients. Thyroid stimulating hormone concentration was raised in 21 euthyroid patients (range $5 \cdot 0-19 \cdot 7 \mathrm{mU} /$ ) and four hyperthyroid patients (range $5 \cdot 0-11 \cdot 4 \mathrm{mU} / \mathrm{l}$ ).

Table IV shows the diagnostic sensitivity, specificity, and false positive rate $^{15}$ for each test, calculated using the conventional and new reference ranges.

\section{FOLLOW UP OF PATIENTS}

In 10 clinically euthyroid patients the thyroid stimulating hormone concentration was $>10 \mathrm{mU} / \mathrm{l}$. At a subsequent follow up clinic when the routine biochemical results were available (total thyroxine, total triiodothyronine, and thyroid stimulating hormone; free thyroxine and free triiodothyronine were not reported routinely) the examining physician still considered that eight of the patients should continue to take the same dose of thyroxine. In two patients the dose was increased, in one on the basis of the biochemical findings (thyroxine $88 \mathrm{nmol} / 1(6.8 \mu \mathrm{g} / 100 \mathrm{ml})$; triiodothyronine $1.3 \mathrm{nmol} / \mathrm{l}(0.8 \mathrm{ng} / \mathrm{ml})$; thyroid stimulating hormone $14.0 \mathrm{mU} / \mathrm{l})$ and in the other, who had Pendred's syndrome, to suppress a goitre (thyroxine $74 \mathrm{nmol} / \mathrm{l}(5 \cdot 8 \mathrm{\mu g} / 100 \mathrm{ml})$; triiodothyronine $1.3 \mathrm{nmol} / 1(0 \cdot 8 \mathrm{ng} / \mathrm{ml})$; thyroid stimulating hormone $14 \cdot 3 \mathrm{mU} / \mathrm{l}$ ).

Three of the 22 patients who were clinically over-replaced had been treated for thyroid carcinoma and were being maintained on a high dose of

TABLE I-Results of biochemical thyroid function tests in 148 treated hypothyroid patients

\begin{tabular}{|c|c|c|c|c|c|c|}
\hline & \multicolumn{2}{|c|}{ Euthyroid patients $(\mathrm{n}=108$ : } & \multicolumn{2}{|c|}{ Hyperthyroid patients $(\mathrm{n}=22)$} & \multicolumn{2}{|c|}{ Hypothyroid patients $(\mathrm{n}=18)$} \\
\hline & Mean $(\mathrm{SD})$ & Range & Mean $(\mathrm{SD})$ & Range & Mean (SD) & Range \\
\hline Total thyroxine $(\mathrm{nmol} / \mathrm{l})$ & $134(32)$ & $48-236$ & $175(59)$ & $94-300$ & $95(34)$ & $43-156$ \\
\hline Free thyroxine $(\mathrm{pmol} / \mathrm{l})$ & $23(7)$ & $8-41$ & $37(20)$ & $15-95$ & $17(8)$ & $7-39$ \\
\hline Total triiodothyronine $(\mathrm{nmol} / \mathrm{l})$ & $1.9(0.4)$ & $1 \cdot 3-3 \cdot 1$ & $2 \cdot 1(0 \cdot 4)$ & $1 \cdot 4-3 \cdot 3$ & $1 \cdot 7(0 \cdot 4)$ & $1 \cdot 0-2 \cdot 3$ \\
\hline Free triiodothyronine $(\mathrm{pmol} / \mathrm{l})$ & $5 \cdot 5(1.5)$ & $2 \cdot 1-12 \cdot 3$ & $6.9(1.9)$ & $3 \cdot 6-11 \cdot 4$ & $4 \cdot 2(1 \cdot 4)$ & $2 \cdot 1-6 \cdot 4$ \\
\hline Thyroid stimulating hormone ${ }^{\star}(\mathrm{mU} / \mathrm{l})$ & & $<0 \cdot 1-19 \cdot 7$ & & $<0 \cdot 1-14 \cdot 4$ & & $<0 \cdot 1-123 \cdot 5$ \\
\hline
\end{tabular}

*Thyroid stimulating hormone was undetectable $(<0 \cdot 1 \mathrm{mU}$. 1) in 34 euthyroid, nine hyperthyroid, and three hypothyroid patients, so the mean was not calculated.

Conversion: SI to traditional units-Total thyroxine: $1 \mathrm{nmol} / 1=0.08 \mu \mathrm{g} 100 \mathrm{ml}$. Free thyroxine: $1 \mathrm{pmol} / \approx 00.8 \mathrm{pg} / \mathrm{ml}$. Total triiodothyronine: $1 \mathrm{nmol} /=0.65 \mathrm{ng} \mathrm{ml}$. Free triiodothyronine: $1 \mathrm{pmol} / 1=0.65 \mathrm{pg} / \mathrm{ml}$

TABLE II-Reference ranges for thyroid function tests

\begin{tabular}{lcc}
\hline & $\begin{array}{c}\text { Conventional } \\
\text { range }\end{array}$ & $\begin{array}{c}\text { Range for } \\
\text { patients receiving thyroxine }\end{array}$ \\
\hline Total thyroxine $(\mathrm{nmol} / \mathrm{l})$ & $55-144$ & $90-195$ \\
Free thyroxine $(\mathrm{pmol} / \mathrm{l})$ & $9-25$ & $12-36$ \\
Total triiodothyronine $(\mathrm{nmol} / \mathrm{l})$ & $0 \cdot 9-2 \cdot 8$ & $1 \cdot 3-2 \cdot 7$ \\
Free triiodothyronine $(\mathrm{pmol} / \mathrm{l})$ & $2 \cdot 9-8 \cdot 9$ & $3 \cdot 0-8 \cdot 6$ \\
Thyroid stimulating hormone $(\mathrm{mU} / \mathrm{l})$ & $0 \cdot 35-5 \cdot 0$ & $<0 \cdot 1-13 \cdot 7$ \\
\hline
\end{tabular}

Conversion: SI to traditional units-Total thyroxine: $1 \mathrm{nmol} / 1 \approx 0.08 \mu \mathrm{g} / 100 \mathrm{ml}$. Free thyroxine: $1 \mathrm{pmol} / \mathrm{l} \approx 0 \cdot 8 \mathrm{pg} / \mathrm{ml}$. Total triiodothyronine: $1 \mathrm{nmol} / \approx \approx 0 \cdot 65 \mathrm{ng} / \mathrm{ml}$. Free triiodothyronine: $1 \mathrm{pmol} / 1 \approx 0 \cdot 65 \mathrm{pg} / \mathrm{ml}$. thyroxine. Two patients were maintained on their original dose as their biochemical findings were "normal." One patient died of a stroke before the dose of thyroxine could be reduced, but in this case the biochemical findings would have been compatible with a euthyroid state. Two patients were lost to follow up. Of the 14 remaining patients, whose dose of thyroxine was reduced, 12 were maintained on a lower dose. The remaining two patients felt unwell with the reduced dose and reverted to their original dose. In these two patients the biochemical results were thyroxine $204 \mathrm{nmol} / \mathrm{l}(15.9 \mu \mathrm{g} / 100$ $\mathrm{ml})$, triiodothyronine $3 \cdot 3 \mathrm{nmol} / 1(2 \cdot 1 \mathrm{ng} / \mathrm{ml})$, and thyroid stimulating hormone $<0.1 \mathrm{mU} / \mathrm{l}$ and thyroxine $135 \mathrm{nmol} / 1(10.5 \mu \mathrm{g} / 100 \mathrm{ml})$, triiodothyronine $2.4 \mathrm{nmol} / 1(1.6 \mathrm{ng} / \mathrm{ml})$, and thyroid stimulating hormone $0 \cdot 1 \mathrm{mU} / 1$, respectively.

TABLE III-Numbers of patients misclassified by conventional and new reference ranges (figures are numbers of patients falling below and above ranges)

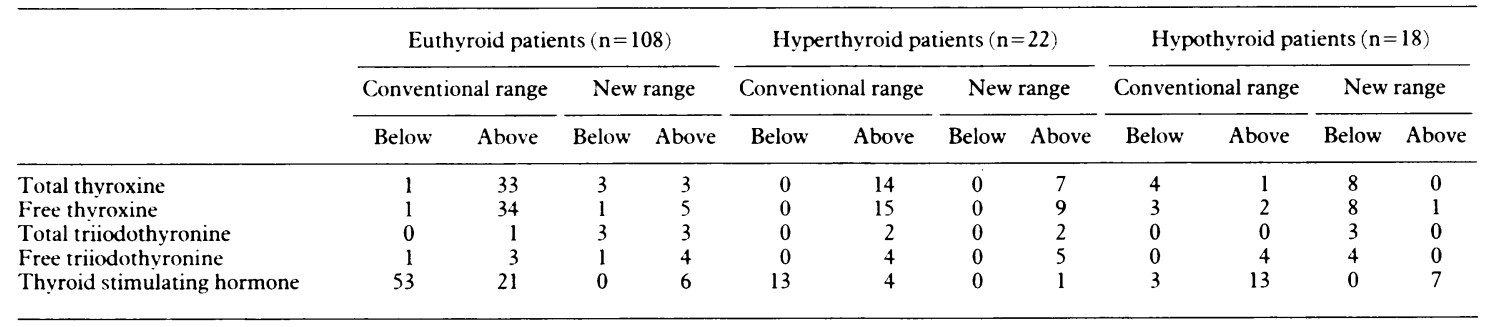

TABLE IV-Diagnostic sensitivity, specificity, and false positive rate of thyroid function tests

\begin{tabular}{|c|c|c|c|c|c|c|}
\hline \multirow[b]{2}{*}{ Test } & \multicolumn{2}{|c|}{ Sensitivity $(\%)$} & \multicolumn{2}{|c|}{ Specificity $(\%)$} & \multicolumn{2}{|c|}{ False positive rate (\%) } \\
\hline & Hyperthyroid patients & Hypothyroid patients & Hyperthyroid patients & Hypothyroid patients & Hyperthyroid patients & Hypothyroid patients \\
\hline \multicolumn{7}{|c|}{ Conventional reference range } \\
\hline Total thyroxine & 64 & 22 & 69 & 99 & 70 & 20 \\
\hline Free thyroxine & 68 & 17 & 69 & 99 & 69 & 25 \\
\hline Total triiodothyronine & 9 & - & 99 & - & 33 & - \\
\hline Free triiodothyronine & 18 & - & 97 & - & 43 & - \\
\hline Thyroid stimulating hormone & 59 & 72 & 51 & 80 & 80 & 63 \\
\hline \multicolumn{7}{|c|}{ New reference range } \\
\hline Total thyroxine & 32 & 44 & 96 & 96 & 30 & 33 \\
\hline Free thyroxine & 41 & 44 & 95 & 99 & 36 & 12 \\
\hline Total triiodothyronine & 9 & 17 & 97 & 96 & 60 & 67 \\
\hline Free triiodothyronine & 23 & 22 & 96 & 99 & 44 & 20 \\
\hline Thyroid stimulating hormone & - & 39 & - & 94 & - & 50 \\
\hline
\end{tabular}


Two of the 18 patients who were clinically hypothyroid had angina, and it was considered that their dose should not be increased. In another patient the dose was increased but subsequently decreased because of worsening angina. One patient was non-compliant when the dose was increased as she felt anxious and sweaty, and she was maintained on the original dose. One patient with a thyroid stimulating hormone concentration of $58 \mathrm{mU} / \mathrm{l}$ died before she was seen at a follow up clinic. One patient was maintained on the original dose because of the biochemical results (thyroxine $116 \mathrm{nmol} / \mathrm{l}$ $(9 \cdot 0 \mu \mathrm{g} / 100 \mathrm{ml})$, triiodothyronine $1.5 \mathrm{nmol} / 1(1 \cdot 0 \mathrm{ng} / \mathrm{ml})$, and thyroid stimulating hormone $11.0 \mathrm{mU} / \mathrm{l})$. The remaining 12 patients were maintained on increased doses.

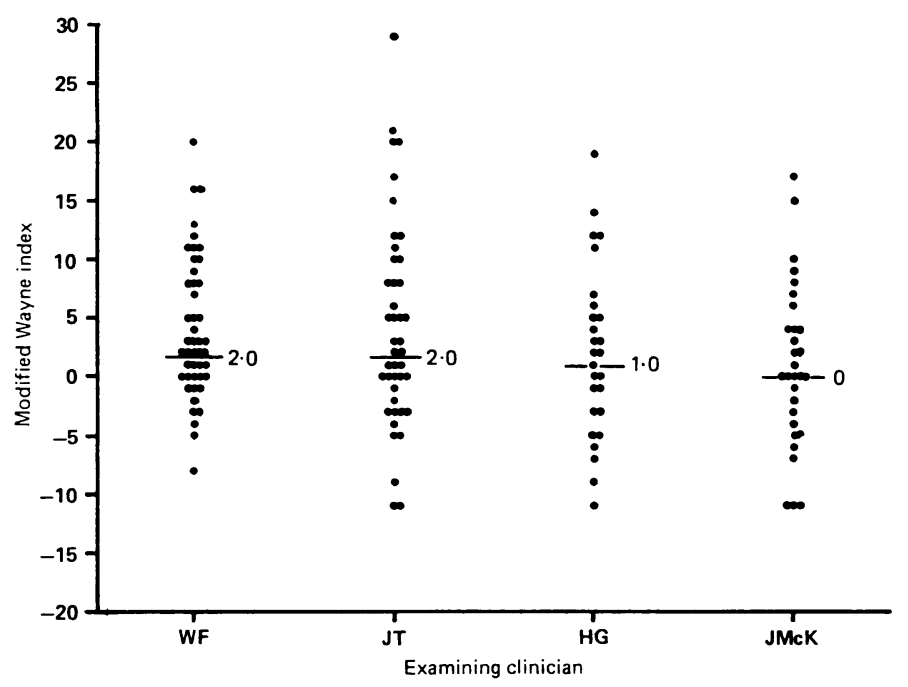

Distribution of modified Wayne index scores assigned to patients by the four examining clinicians. Horizontal bars represent median scores.

\section{Discussion}

Our major assumption in this paper is that the clinical assessment of patients receiving thyroxine replacement by doctors experienced in thyroid disease is correct. We tried to establish the role of biochemical measurement of thyroid hormone concentrations in helping in this diagnosis.

At present there is no variable that can readily be measured satisfactorily to assess the end organ response to thyroid hormone action in patients receiving thyroxine replacement. The serum concentration of thyroid stimulating hormone is unsatisfactory as the thyrotrophs in the anterior pituitary are more sensitive to changes in the concentration of thyroxine in the circulation than other tissues, which rely more on triiodothyronine. ${ }^{16}$

Our data indicate that the reference ranges for serum total thyroxine, analogue free thyroxine, and thyroid stimulating hormone in patients receiving thyroxine replacement are different from conventional reference ranges. It is clear from table IV, however, that serum thyroid hormone and thyroid stimulating hormone concentrations cannot be used with any degree of confidence to classify patients as receiving satisfactory, insufficient, or excessive amounts of thyroxine replacement. There is little difference between the ability of concentrations of total and analogue free thyroxine to detect over-replacement; the poor diagnostic sensitivity and high false positive rate associated with such measurements render them virtually useless in clinical practice. Concentrations of total triiodothyronine, analogue free triiodothyronine, and thyroid stimulating hormone are also incapable of satisfactorily indicating over-replacement. The tests perform equally badly in detecting under-replacement.

A question that remains to be answered convincingly is whether it is clinically necessary to measure thyroid hormone concentrations in patients receiving thyroxine replacement. The standard replacement dose in Europe and America was 200-400 $\mu$ g day until 1973, when it was halved to $100-200 \mu \mathrm{g}$ a day on the basis of biochemical measurements of thyroid hormone concentrations. ${ }^{1718} \mathrm{We}$ are not aware of any study that has shown that this reduction in the standard dose has had any clinically beneficial effects. Different groups have shown changes in sodium metabolism, ${ }^{19}$ hepatic enzyme activity in serum, ${ }^{5}$ and systolic ejection time intervals ${ }^{3}$ in patients receiving high doses of thyroxine, but such measurements have not been shown to be of any relevance to patient care.

We consider that biochemical tests of thyroid function are of little, if any, value clinically in patients receiving thyroxine replacement. Most patients are rendered euthyroid by a daily dose of 100 or $150 \mu \mathrm{g}$ of thyroxine. Further adjustments to the dose should be made according to the patient's clinical response. In our laboratory $36 \%$ of all thyroid function tests are performed to monitor thyroxine replacement. To stop doing these tests in such patients would cause considerable saving in the costs of reagents in laboratories using commercial kits.

Our findings emphasise the need for laboratories to make their users aware that the reference ranges for serum thyroxine, free thyroxine, and thyroid stimulating hormone concentrations in patients receiving thyroxine replacement are considerably different from the conventional ranges; they should also point out the limitations of these ranges. This is especially important for general practitioners and non-specialists, who generally rely on the biochemical findings more than specialist endocrinologists do in managing these patients. The conclusions in this paper also have major implications for schemes such as the Scottish Automated Follow-Up Registry, ${ }^{20}$ which relies on results of thyroid function tests in assessing patients treated by radioiodine or thyroid surgery.

\section{References}

1 Midgeley JEM, Wilkins TA. The direct estimation of free hormones by a simple equilibrium radioimmunoassay. Amersham: Radiochemical Centre, 1981.

2 Wehmann RE, Nisula BC. Radioimmunoassay of human thyrotropin. Analytical and clinical developments. CRC Crit Rev Clin Lab Sci 1984;20:243-83.

3 Jennings PE, O'Malley BP, Griffen KE, Northover B, Rosenthall FD. Relevance of increased serum thyroxine concentrations associated with normal serum triiodothyronine values in hypothyroid patients receiving thyroxine: a case for "tissue thyrotoxicosis." $\mathrm{Br}$ Med $\mathrm{f}$ 1984;289:1645-7.

4 Rendell M, Salmon D. Chemical hyperthyroidism: the significance of elevated serum thyroxine levels in L-thyroxine treated individuals. Clin Endocrinol 1985;22:693-700.

5 Beckett GJ, Kellett HA, Gow SM, Hussey AJ, Hayes JD, Toft AD. Raised plasma glutathione $\mathrm{S}$-transferase values in hyperthyroidism and in hypothyroid patients receiving thyroxine $S$-transferase values in hyperthyroldism and in hypothyroid patients
replacement: evidence for hepatic damage. Br Med f 1985;291:427-31.

6 Pearce CJ, Himsworth RL. Total and free thyroid hormone concentrations in patients receiving maintenance replacement treatment with thyroxine. Br Med f 1984;288:693-5.

7 Oldfield S, Ramsden DB, Stephens KE, Barrington H, Hall RA, Milles JJ. Conflict between classifications based on free thyroxine and thyroid stimulating hormone concentrations in thyroxine-treated patients. Clin Chim Acta 1985;145:307-11.

8 Caldwell G, Kellett HA, Gow SM, et al. A new strategy for thyroid function testing. Lance $1985 ;$ i: $1117-9$.

9 Toft AD. Thyroxine replacement treatment: clinical judgment or biochemical control? $\mathrm{Br} \mathrm{Med} \mathrm{F}$ 1985;291:233-4.

10 Allen KR, Scott RDM, Hewitt JV, Watson D. Clinical value of a sensitive, immunoradiometric assav for TSH. Ann Clin Biochem 1985;22:506-8.

11 Johansen K, Hansen JM, Skovster L. The relationship between levels of thyroid stimulating hormone and of thyroxine and triiodothyronine in blood of hypothyroid patients. Acta Endocrinol (Copenh) 1978;88:691-9.

12 Kurtz AB, Dryer K, Capper SJ, Von Borcke S, Ekins RP. Free thyroid hormone concentrations in serum from patients on thyroxine replacement therapy. Nucl Med Commun 1980;1:28-32.

13 Wayne EJ. Clinical and metabolic studies in thyroid disease. Br Med f 1960;i:1-11, 78-90.

14 Biggart EM, Paterson N, Gillespie $S$, et al. Potency differences in immunometric assays for serum TSH. f Endocrinol 1985; 104(suppl): 125.

15 Galen RS, Gambino SR. Beyond normality: the predictive value and efficiency of medical diagnosis. New York: John Wiley, 1975.

16 Larsen PR, Silva JE, Kaplan MM. Relationships between circulating and intracellular thyroid hormones: physiological and clinical implications. Endocr Rev 1981;2:87-102.

17 Evered D, Young ET, Ormston BJ, Menzies R, Smith PA, Hall R. Treatment of hypothyroidism: a reappraisal of thyroxine therapy. BrMed f 1973;iii:131-4.

18 Stock JM, Surks MI, Oppenheimer JH. Replacement dosage of L-thyroxine in hypothyroidism. N Engl f Med 1974;290:529-33.

19 Bell GM, Sawers JSA, Forfar JC, Doig A, Toft AD. The effect of minor increments in plasma thyroxine on heart rate and urinary sodium excretion. Clin Endocrinol (Oxf) 1983;18:511-6.

20 Scottish Automated Follow-Up Register Group. Thyroxine replacement therapy: prescribing patterns and problems in 2710 patients. Br Med $\mathcal{J}$ 1980;281:969-71.

(Accepted 22 fuly 1986) 